\title{
HISTORICAL DETERMINANTS OF INCLUSIVE EDUCATION DEVELOPMENT
}

\author{
Iryna Sadova \\ Associate Professor, PhD, Drohobych Ivan Franko State Pedagogical University, \\ e-mail: iryna-sadova@ukr.net, orcid.org/0000-0003-2570-5392, Ukraine
}

\begin{abstract}
The prerequisites for the emergence and development of educational inclusion in Ukraine and abroad have been substantiated in the article. The experience of organizing the education of children with psychophysical disorders and the influence of sociopolitical phenomena on this process have been analyzed. The tendencies of the development of inclusive education in the countries of Western Europe and possibilities of their creative use taking into account the specifics of domestic realities have been expressed. The evolution of the attitude of the public and the state towards people with psychophysical disorders has been characterized - from complete non-recognition and even destruction to segregation integration - inclusion. Based on the historical and pedagogical research, prospects of development of inclusive education in terms of national pedagogical theory and practice have been determined.
\end{abstract}

Keywords: segregation, integration, inclusion, special educational needs (SEN), people with psychophysical disorders.

\section{DOI: http://dx.doi.org/10.23856/3708}

\section{Introduction}

The concept of inclusive education proclaimed by some of the most developed countries is one of the priority directions for improving the world policy and educational system. Its goal is to improve the quality of secondary education of children with psychophysical disorders in accordance with their educational needs. The analysis of domestic and foreign scientific sources shows that the emergence of social and educational phenomenon of "inclusive education" is primarily associated with a turning point in the public attitude towards people with psychophysical disorders. For many decades, the effective strategies for inclusive education aiming to create a truly humanistic society have been the focus of numerous scientific and pedagogical discussions. An inclusive culture becomes the fundamental basis of such society.

The effective directions for the implementation of inclusive education as an important stage in the global development of mankind have been developed nowadays due to productive international cooperation and teachers' scientific-practical activities. Modern researchers are finding out the determinants of the formation of inclusive education, singling out its structural, content and methodological components and defining strategies for its effective implementation. The topicality of this problem consists primarily in the fact that education as the most important socio-cultural human right and the public sphere of life significantly affects the development of the individual. In this regard, the appeal to almost half a century's world experience in this area, its study and critical analysis, consideration of the possibility of its use considering the specificity of the domestic context, appears to be topical and significant for the Ukrainian educational system. 


\section{Periods of Inclusive Education Development}

Changes in the modern educational system are determined by legal and social aspects in the process of social development (Florian, 2008). Inclusive education is based on the worldview principles of social inclusion since its equality, accessibility and quality assurance are the fundamental imperatives of its functioning (Sadova, 2019: 92). These transformations primarily guarantee the citizens' rights, freedoms as well as legitimate interests in the field of education; its accessibility at all levels and for all people, including those with psychophysical disabilities (considering their health status and cognitive capabilities) (Norwich, 2013).

Many teachers, scientists and doctors have joined in the elimination of former stereotypes in the public consciousness as to psychologically minded children and adults. The attitude of the public and the state to people with psychophysical disorders has undergone a gradual evolution for 2500 years. There are five periods of the evolution from hatred and aggression to inclusion. However, according to most researchers the process of evolution finished much earlier in Western Europe than in Ukraine.

Historical facts testify to the steady and gradual humanization of the public acceptance of people with certain developmental disabilities - a transition from complete exclusion to inclusion through segregation and integration (Oliver, Barnes, 1994).

So, the researches have defined five distinct characteristic periods of the public acceptance of people with certain developmental disabilities:

1. The period going from fear, aggression and intolerance to the awareness of the need to take care of the disabled (9th-8th centuries BC - 12th century AD).

2. The period going from attempts to meet the children with developmental disabilities' physical needs to justification of possibilities on training children with visual and hearing impairments - first individually, in shelters, and later in the first special educational institutions (12th century - the late 18th century).

3 . The period of the recognition of the need to provide education for the three groups of disabled children: with intellectual disability, hearing impairment and vision impairment (the late 18 th century - the early 20th century).

4. The period of the formation of the differentiated system of special education (the beginning of the 20th century - the second half of the 20th century).

5. The period going from the former isolation of disabled children to their integration with healthy peers in educational institutions and inclusion (the second half of the 20th century - till today).

Now let's briefly describe each of these five stages.

The first period (9th-8th centuries BC - 12th century AD) began in the Age of Antiquity. It started at the time when the foundations of a fixed-time approach to children with different appearance were laid for (Barnes, Mercer, Shakespeare, 1999). The most striking reflection of the common attitude of ancient society to those children was their total aggressive rejection in Ancient Sparta, Athens and Rome. Despite the difference in the political and social structure of those states, all of them were unanimous in regard to forced euthanasia and isolation of sick and physically weak babies as unnecessary members of society. Unfortunately, such inhumane policy was considered generally recognized in the ancient world (Malofeev, 2003).

Describing the Spartans' customs, a famous ancient historian Plutarch once noted: "The upbringing of a baby did not depend on the father's will, - he brought it to the "Lesha", a meeting place for the oldest members of Philae, where the baby was examined. If the baby 
was strong and healthy, it was given back to the father. However, weak and ugly babies were thrown into the abyss at Taygetus. Disabled and fragile newborns were considered unnecessary" (Plutarch, 1987: 108).

Ancient thinkers Plato (427-347 BC ) and Aristotle (384-322 BC) adopted such inhuman practice from Sparta (Ivanov, 1917). In particular, Aristotle called out his compatriots in the following way: "Let the force have a law according to which no cripples should be fed" (Aristotle, 1976: 7).

However, the public subsequently achieved the introduction of certain restrictions to that cruel ancient law. Leaving children to fend for themselves was considered tantamount to murder. Nevertheless, social isolation of persons with psychophysical disorders still dominated in the society, and they were diprived of their rights for a long time. Thanks to a happy coincidence (believers would call it God's Providence), some of the prominent antique figures with certain developmental disorders escaped death. Among them was a thinker Didymus the Blind, a poet Homer and a fabulist Aesop. More than two millennia have passed since the time when the right to deprive sick children of their lives, legalized by Lycurgus, developed into secular Western European government's charitable initiatives in regard to persons with disabilities (Basova, Egorov, 1984: 70).

Thus, the Middle Ages were a period of complete pedagogical and social isolation of people with psychophysical disabilities.

The first period of the formation of the system of education for children with special needs in Ukraine was characterized by certain peculiarities. Firstly, there was no violent dislike for children with psychophysical disorders in the Kievan Rus. Moreover, the pagan Slavs surrounded them with an aura of sanctity and mystery and treated them sympathetically; ordinary people considered the guardianship of the "blessed ones" a good deed. Secondly, the Kievan princes displayed personal mercy for them. They quickly adopted the experience of Western Europe in organizing special shelters for disabled children and willingly donated part of their income to charity (Kolupaeva, Taranchenko, 2016).

The second period of the public attitude towards children with psychophysical disorders ensured not only care and protection for children with visual and hearing impairments but also enabled the opportunity for their individual training - at first in shelters and later in special educational institutions (12th century - the late 18th century). There occured crucial changes in the social status of disabled children at that time.

The Rennaissance (14th - 16th centuries) enabled the development of the ideology of anthropocentrism and humanism (Basova, Egorov, 1984). The status of children with disabilities changed dramatically after "The Age of Reformation (14th-15th centuries), a socalled "big religious revolution". By then, there could be no question of the church approving of the education of children with psychophysical disorders.

The reformation led to the emergence of another trend in Christianity - Protestantism, which to a certain extent changed the views on charity and influenced the norms of public morality. The rapid urbanization of that time contributed to the rapid development of education and science, the opening of numerous universities and the invention of printing. The invention of printing by the German mechanic and jeweler Johann Guttenberg in 1436 became a turning point in the life of European society of the 15th century. By the year of 1500, there were already 250 printing houses in Europe which published more than 50 thousand copies of works at that time (Malofeev, 2003).

The 17th century entered European civilization as "a period of triumph". The interest in man as the highest social value and unique personality was rapidly increasing, and the belief 
in the need for his harmonious development was strengthening (Komensky, 1955: 206-207).

So, within the analyzed periods of the public attitude towards persons with mental and physical disabilities, the second stage is characterized by the transition from the nobility's charitable initiations and fundraisers in order to enable individual training for disabled children to the opening of the first educational institutions for the deaf and blind. Throughout the history of the formation of special education in our country, there is no data on individual training of persons with sensory disorders during the time period under analysis. However, the absence of such information gave grounds for the conclusion that Ukraine adopts the already existing Western model of organizing special schools for not having experience of individual training of such children.

The third period in the public perception of children with psychophysical disorders going from the assimilation of the possibility to the assimilation of the necesity to provide education for children with intellectual disability, hearing and vision impairments (the late 18th century - early 20th century). Western Europe entered that stage under the slogan "People are born and remain free and equal in their rights" (and remain 1793). The upper limit of that time period is considered to be the opening of the first school for the deaf and dumb in France (1770), and subsequently for the blind (1784), that was the first time when the legal status of children with disabilities had been changed: most European countries recognized their right to education, guaranteed them social assistance as well as the responsibility for the implementation of this right (Malofeev, 2003). The adoption of the law on free primary education gave rise to the rapid development of the system of special educational institutions in the countries that were the centres of scientific, cultural and political life at that time (Australia, Denmark, Italy, Germany, Sweden) and the development of goals and methods of education for children with special needs and the consideration of the sources of its funding.

The analysis of the third period shows that the first attempts to teach children with psychophysical disorders were made in regard to people with sensory disorders (Winzer, 1993). The information about the implementation of the idea of integrated education for both disabled and able-bodied children was very ristricted. That happened, in our opinion, due to the prevailing ideas on the part of the state about its inexpediency.

Most researchers focus on France's leading role not only in the formation of the educational system for children with psychophysical disorders, but also in attempts to implement an integrated approach to it. Since the end of the 18th century French scientists (J. Itar, E. Seguin, L. Braille, V.Haüy, G. Sikar, etc) didn't only purposefully lay foundations for providing education for such children, but also achieved great practical results in this area, especially in France. Later their experience was adopted by experts from other countries.

During 1817-1923 Western European countries adopted regulations on compulsory special education. Mass opening of educational institutions for the deaf and blind children in the second half of the 19th century contributed to the abolition of serfdom (1861) and the adoption of new Regulations for primary schools, which legalized their functioning on the initiative of local authorities and communities (1864).

As we can see, the first attempts to integrate education of healthy and disabled children took place in the second half of the 19th century. By the beginning of the twentieth century, many special educational institutions for the three groups of disabled children - those with intellectual disability, hearing and vision impairments - had already been functioning in Western Europe.

In the Soviet Union, including Ukraine, the practice of co-education of students with 
disabilities and able-bodied students was constantly supported, developed and widely discussed at various pedagogical meetings. Turning children of special needs into useful citizens was considered to be he main task at that time. In particular, a new resolution was adopted at the Second All-Russian Soviet Congress on social and legal protection of minors in 1924. The resolution noted: "...the blind have the right to enter general educational institutions for the sighted... in each individual case with the permission of the governing body when there are grounds to expect them to meet the basic requirements set down for their sighted companions" (Kolupaieva, Taranchenko, 2016:12) The resolution of the Central Committee of the CPSU (b) "On General education" did not contain a separate article about children with psychophysical disorders and, accordingly, extended to them the standards of education for healthy students. Later another resolution of universal compulsory primary education of children (boys and girls) at the age of 8,9 and 10 on a four-year course of study was introduced in the USSR between 1930 and 1931. The primary school curriculum in special institutions for the disabled was designed for 5 years for the blind and those with intellectual disabilities, and for 7 years for the deaf and dumb.

The fourth period in the evolution of relations between the public and children with psychophysical disorders - a transition from individual training of children with disabilities to a differentiated system of inclusive education (the beginning of the 20th century - the end of the XX century.). Its upper time limit in each country can be considered the time of adoption and implementation of the law on universal compulsory primary education as well as the acts on the education of children with psychophysical disorders.

By 1914, most Western European countries had legalized the system of special education and outlined the prospects for its development. However, its practical implementation was prevented by World War I. The ideas of humanistic pedagogy developing in the difficult conditions of the war and post-war period later became the basis of integration processes. For example, let's recall the activities of the Italian teacher M. Montessori (18701952). Her methods, based on the recognition of the special educational needs of children, coincided with the principles of inclusion. M. Montessori began her practical work in a children's psychiatric clinic where, under the influence of the ideas of J. ITAR and E. SEGUIN, she devised a method for developing the senses in children with intellectual disabilities. The scientist successfully tested her theoretical achievements in the "children's home" founded by her (1907) for children from 3 to 6. (Montessori, 1989). However, M. Montessori did not receive any help or support from the state. In 1922, the fascists came to power in Italy. Their anti-human regime slowed down the development of the special education system for many years. M. Montessori emigrated from Italy and actively promoted the ideas of humanistic pedagogy in France, Great Britain, Spain and other countries.

In 1945 the United Nations (UN) drew the world's attention to the problem of ensuring equal rights of children with psychophysical disabilities to obtain a quality education. The development of integration processes in the educational system was caused by the need to implement such international legal acts, adopted at the initiative of the UN, as: "Universal Declaration of Human Rights" (1948); "Declaration of the Rights of the Child" (1959); "Declaration on the Rights of People with Disabilities" (1975); "Convention on the Rights of the Child" (1989); "World Declaration on Education for all" (1990); "Salamanca Statement on Principles, Policy and Practice in Special Needs Education" (1994); Dakar framework for action "Education for All" (2000).

The second half of the 20th century was the time of the improvement of the special education national system: the transition from 3 to 8 types of special schools was carried out. 
The change in attitudes towards people with psychophysical disorders coincided with the collapse of the Soviet Union. Declaring itself an independent democratic state on September 27, 1991, Ukraine ratified the UN Convention on the rights of children on December 16, 2009 - "Convention on the Rights of Persons with Disabilities".

Thus, by the end of the fourth period, the countries had already reached a certain level of their economical, legal and cultural developmental goals. New social order for the implementation of the integrated education was formulated. It aimed to define the rights of persons with disabilities and their equal opportunities in different areas of life, including education, and re-evaluate their attitude to them.

Lastly, here is a short description of the fifth and the last period of public attitude towards persons with psychophysical disorders. This is a stage of transition from isolation of children with special needs to their integration with healthy peers in educational institutions and inclusion (the late 20th century - till today).

Since the end of the 1970 s, children with psychophysical disorders have been training in an inclusive environment in secondary schools. In Ukraine this process began in the 90s, with a radical reformation of the state structure. During the 1991-2000s, integrated education of persons with psychophysical disorders and able-bodied persons, with the participation of specialist teachers for inclusive practice and application of special methods and tools, has become increasingly inclusive of persons with disabilities in the national educational system.

Various European countries have recognized the value of integration in different periods (Ainscow, Sandhill, 2010). The Netherlands, Norway, and Sweden have adopted the most advanced laws in this context. All of them effectively implement UNESCO programs, in particular "Education for all", aimed to attract the children who previously had no opportunity to attend schools to the educational process.

Among the domestic acts of Ukraine we have singled out the Constitution of Ukraine (1996), the Law of Ukraine "On Approving the Procedure for Organizing Inclusive Education in General Secondary Education Institutions" (2008). The law "On Education" (2017) regulates the development of special education for people with psychophysical disabilities and contains a number of articles that enshrine the right of children to obtain a quality education in accordance with their abilities and needs.

Consequently, the last period in the evolution of relations between society and children with psychophysical disorders is characterized by an increase in the education integration processes which is significantly facilitated by the collaboration among teachers, the children's parents and the representatives of public organizations. The children with special needs problems' are being solved at the state level, especially those concerning their education in secondary schools.

\section{Conclusions and suggestions}

So, the historiographical analysis of the scientific sources gave grounds to state that the gradual transition to the implementation of inclusive education of children with psychophysical disorders has its own peculiarities due to the stage of the society development. However, there are common tendencies of this process in any society, namely:

1) change of public attitudes towards inclusion of children with disabilities;

2) icreasing attention a state to their problems, in particular the educational issues;

3) adoption of a number of international legislative documents contributing to the improvement of the national system of special education and further integration of general 
and special education into inclusive education.

\section{References}

Ainscow, M., Sandhill, A. (2010). Developing inclusive education systems: the role of organisational cultures and leadership. International Journal of Inclusive Education, 14 (4), 401-416. DOI: 10.1080/13603110802504903. [in English].

Aristotle. (1976). Metaphysics. Moscow: Mysl'. [in Russian].

Barnes, C., Mercer, G., Shakespeare, T. (1999). Exploring Disabilty: A sociological Introduction. Oxford: Blackwell, 1999. [in English].

Basova, A., Egorov, S. (1984). History of Sign Language Pedagogy. Moscow: Prosveshchenie. [in Russian].

Florian, L. (2008). Special or inclusive education: future trends. British Journal of Special Education, 35(4), 202-208. DOI: 10.1111/j.1467-8578.2008.00402.x. [in English].

Ivanov, K. (1917). Ancient history. Saint Petersburg: Petrograd. [in Russian].

Kolupaieva, A., Taranchenko, O. (2016) Inclusive Education: from the basics to practice: monohrafiya. Kyiv: ATOPOL. [in Ukrainian].

Komensky, Y. (1955). Selected pedagogical works. Moscow: Uchpedgiz. [in Russian].

Malofeev, N. (2003). Western Europe: Evolution of Attitude of Society and State to Persons with developmental disabilities. Moscow: Examen. [in Russian].

Montessori, M. (1989). What You Should Know About Your Child. Oxford, England: Clio press, Cop. [in English].

Norwich, B. (2013). Addressing tensions and dilemmas in inclusive education. London: Routledge. DOI:10.4324/9780203118436. [in English].

Oliver, M., Barnes, C. (2010). Disability studies, disabled people and the struggle for inclusion. British Journal of Sociology of Education, 31(5), 547-560. DOI: 10.1080/01425692.2010.500088. [in English].

Plutarch. (1987). Selected biographies. Moscow: Pravda. [in Russian].

Sadova, I. (2019). The formation of the inclusive preparedness of future teachers of the primary school. Youth and market. Monthly scientific-pedagogical journal, 10 (177), 92-97. DOI: 10.24919/2308-4634.2019.187250. [in Ukrainian].

Winzer, M. (1993). The history of special education: From isolation to integration. Washington. DC: Gallaudet University Press. [in English]. 